\title{
New Synthesis of Heterobifunctional Poly(ethylene glycol) Possessing a Pyridyl Disulfide at One End and a Carboxylic Acid at the Other End
}

\author{
Takehiko IshiI, ${ }^{1}$ Masayoshi Yamada, ${ }^{1}$ Takumi HiRASE, ${ }^{1}$ and Yukio NAGASAKI ${ }^{2, \dagger}$ \\ ${ }^{1}$ Department of Material Science and Technology, Tokyo University of Science, \\ 2641 Yamazaki, Noda 278-8510, Japan \\ ${ }^{2}$ Tsukuba Research Center for Interdisciplinary Materials Science, University of Tsukuba, \\ 1-1-1 Tennodai, Tsukuba 305-8573, Japan
}

(Received October 22, 2004; Accepted November 30, 2004; Published March 15, 2005)

\begin{abstract}
A well-defined poly(ethylene glycol) (PEG) possessing a 2-pyridyldithio end group at one end and a carboxyl group at the other end was prepared after chemical modification of the $\alpha$-allyl- $\omega$-carboxyl PEG, which was synthesized by an anionic ring-opening polymerization of ethylene oxide (EO) using potassium allyl alcoholate as the initiator, followed by the modification of the $\omega$-end-alkoxide group to a carboxyl group using succinic anhydride. The allyl end group was modified by the radical addition reaction of thioacetic acid in the presence of azoisobutyronitrile (AIBN) that led to $\alpha$-thioacetate- $\omega$-carboxyl PEG without any side reaction. Selective hydrolysis of the thioester end group was accomplished by $n$-alkylamine in the presence of 2,2'-dithio pyridine (2-PDS) to give $\alpha$-pyridyldithio- $\omega$ carboxyl PEG with no aminolysis to the oxoester of the carboxyl group of the other end. The functionalities of both ends characterized by NMR spectra, were almost quantitative. [DOI 10.1295/polymj.37.221]

KEY WORDS Heterotelechelic Poly(ethylene glycol) / Mercapto-ended-PEG / Anionic Polymerization / Biomedical Polymers /
\end{abstract}

Recently, PEGylation technology has attracted much attention in the field of surface chemistry, due to its unique biocompatibility ${ }^{1,2}$ derived from its own unique properties such as nontoxicity, solubility and flexibility that induce an effective steric stabilization, ${ }^{3}$ and is applied in the biomedical field of bioconjugation, ${ }^{4-6}$ drug delivery system (DDS ${ }^{7-9}$ and diagnostics. ${ }^{10-13}$ Especially, in the field of bio-interface engineering, it is well known that a surface modified with poly(ethylene glycol) (PEG) as a tethered chain structure dramatically decreases the nonspecific interaction of biopolymers. ${ }^{14}$ Such a non-fouling surface is one of the most suitable devices for specific biorecognition such as single molecular detections, diagnostics and immunoprecipitations.

In order to construct PEG tethered chain surfaces, versatile types of semitelechelic PEGs, which signifies a PEG with a functional group at one end, are utilized. For example, a mercapto-ended PEG can be fixed on a gold surface via a covalent linkage ${ }^{15}$ due to the strong interaction between the gold surface and the mercapto group at the PEG chain end. ${ }^{16,17}$ For further modifications on the PEG tethered chain surface, however, the semitelechelic PEG is not suitable because of the inert free end group of the tethered chain for further derivatization. For a high-performance bio-interface, heterotelechelic PEGs, which denotes a functional group at one end and another functional group at the other chain end, are required. Since the early 90 s, we have been focusing on the selective and quantitative synthesis of heterotelechelic PEGs. Several types of heterotelechelic PEGs have been synthesized, such as CHOPEG-OH,${ }^{18}$ monosaccharide-PEG-OH,${ }^{19} \mathrm{NH}_{2}-\mathrm{PEG}-$ $\mathrm{OH},{ }^{20,21}$ benzaldehyde-PEG-SS-Pyridyl, ${ }^{22} \mathrm{NH}_{2}-$ PEG-COOH ${ }^{23}$ and acetal-PEG-SH. ${ }^{24}$

Among the several types of heterotelechelic PEGs, mercapto-ended homologues can be utilized for gold surface modification as stated above, thus the modification of a biosensor surface such as quartz crystal microbalance $(\mathrm{QCM})$ and surface plasmon resonance (SPR) sensor is feasible. Actually, the biotin-PEGSH was modified on the SPR sensor surface, which played a significant role in both minimizing the nonspecific adsorption and achieving specific recognition of streptavidin, led to a very high $\mathrm{S} / \mathrm{N}$ ratio for the biosensing. ${ }^{25}$

For the preparation of the PEG tethered chain surface coupled with specific proteins, such as an antibody and enzyme, an active ester group at the free chain end is the most useful. The objective of this work was to effectively synthesize a PEG having a carboxylic group at one end and a mercapto group at the other chain end. This type of heterotelechelic PEG can be utilized for the construction of a PEG tethered chain having a carboxylic group at the free chain end on the gold surface. 


\section{EXPERIMENTAL}

\section{Materials}

Tetrahydrofuran (THF) and allyl alcohol were purified by conventional methods. Ethylene oxide (EO) (Sumitomo Seika) was dried over calcium hydride and distilled under an argon atmosphere. Potassium naphthalene was used as a THF solution, whose concentration was determined by titration. Succinic anhydride was recrystallized from THF and washed with diethyl ether, dried in vacuo, and then dissolved in dry THF (0.7 M). Azoisobutyronitrile (AIBN) (Wako) was recrystallized from methanol and dried in vacuo. Thioacetic acid, 2,2'-dithiodipyridine (2-PDS) (Tokyo Kasei Kogyo), $n$-propylamine (Wako), $N$-hydroxysuccinimide (NHS) (Acros Organics), $N$-ethyl- $N^{\prime}-$ (3-dimethylaminopropyl)carbodiimide hydrochloride (EDC) (Pierce), human IgG (Cappel), anti-human IgG (Rockland) and all other reagents were used as received. A gold sensor chip (SIA kit Au) for SRP measurements was purchased from Biacore AB.

Synthesis of PEG Having an Allyl Group at One End and a Carboxylic Acid Group at the Other Chain End (Allyl-PEG-COOH)

PEG possessing an allyl group at the $\alpha$-chain end was prepared by the anionic polymerization of EO initiated with potassium allyl alcoholate as follows: the allyl alcohol $(2.0 \mathrm{mmol})$ and THF $(50 \mathrm{~mL})$ were added to a $100 \mathrm{~mL}$ round-bottom flask containing an argon atmosphere. THF solution of potassium naphthalene $(2.0 \mathrm{mmol})$ was then added to prepare potassium allyl alcoholate. After stirring for several minutes, a liquid EO (91.6 mmol) was added to the mixture via a cooled syringe. After the stirring of the mixture for $2 \mathrm{~d}$ at room temperature, a THF solution of succinic anhydride $(2.2 \mathrm{mmol})$ was added to the reaction mixture to convert the $\omega$-end alcoholate group to a carboxyl group. ${ }^{26,27}$ The mixture was further stirred for several hours. The obtained polymer was precipitated into an excess amount of diethyl ether and separated by filtration. The precipitate was dried in vacuo and then analyzed by size-exclusion chromatography (SEC). The number-average molecular weight $\left(M_{\mathrm{n}}\right)$ and the molecular weight distribution (MWD) were determined to be 2,030 and 1.08, respectively. ${ }^{1} \mathrm{H}$ NMR (400 $\left.\mathrm{MHz}, \mathrm{DMSO}-d_{6}\right): \delta 5.85-6.00\left(\mathrm{~m}, 1 \mathrm{H}, \mathrm{CH}_{2}=\mathrm{CH}-\right)$, 5.15-5.30 (dd, 2H, $\left.\mathrm{CH}_{2}=\mathrm{CHCH}_{2}-\right), 4.05-4.15(\mathrm{t}$, $\left.2 \mathrm{H},-\mathrm{CH}_{2} \mathrm{CH}_{2} \mathrm{OC}(=\mathrm{O})-\right), 3.98-4.05\left(\mathrm{~d}, 2 \mathrm{H}, \mathrm{CH}_{2}=\right.$ $\left.\mathrm{CHCH}_{2} \mathrm{O}-\right), 3.40-3.85$ (m, $\left.184 \mathrm{H},-\mathrm{CH}_{2} \mathrm{CH}_{2} \mathrm{O}-\right)$, 2.58-2.62 (t, $\left.4 \mathrm{H},-\mathrm{C}(=\mathrm{O}) \mathrm{CH}_{2} \mathrm{CH}_{2} \mathrm{C}(=\mathrm{O})-\right)$.
Synthesis of PEG Possessing a Thioester Group at One End and Carboxylic Acid Group at the Other Chain End $\left(\mathrm{CH}_{3} \mathrm{C}(=\mathrm{O}) \mathrm{S}-\mathrm{PEG}-\mathrm{COOH}\right)$

The obtained allyl-PEG-COOH $(0.2 \mathrm{mmol})$, thioacetic acid $(20 \mathrm{mmol})$ and AIBN $(0.08 \mathrm{mmol})$ were dissolved in $50 \mathrm{~mL}$ of methanol in a $100 \mathrm{~mL}$ of roundbottom quartz glass flask, followed by argon bubbling with a gentle flow for $30 \mathrm{~min}$ to eliminate any dissolved oxygen. The mixture was irradiated for $12 \mathrm{~h}$ with a $250 \mathrm{~mW} / \mathrm{cm}^{2}$ (at $365 \mathrm{~nm}$ ) UV light source. After concentration of the solution, the obtained polymer was precipitated into diethyl ether and separated by filtration. The precipitate was dried in vacuo. ${ }^{1} \mathrm{H}$ NMR $\left(400 \mathrm{MHz}, \mathrm{CDCl}_{3}\right): \delta 4.20-4.25(\mathrm{t}, 2 \mathrm{H}$, $\left.-\mathrm{CH}_{2} \mathrm{CH}_{2} \mathrm{OC}(=\mathrm{O})-\right), 3.40-3.85\left(\mathrm{~m}, 184 \mathrm{H},-\mathrm{CH}_{2}-\right.$ $\left.\mathrm{CH}_{2} \mathrm{O}-\right), 2.81$ (t, 2H, $\left.-\mathrm{SCH}_{2} \mathrm{CH}_{2} \mathrm{CH}_{2}-\right), 2.58-2.62$ (t, $\left.4 \mathrm{H},-\mathrm{C}(=\mathrm{O}) \mathrm{CH}_{2} \mathrm{CH}_{2} \mathrm{C}(=\mathrm{O})-\right), 2.31 \quad\left(\mathrm{~s}, 3 \mathrm{H}, \mathrm{CH}_{3}-\right.$ $\mathrm{C}(=\mathrm{O}) \mathrm{S}-), 1.80-1.95\left(\mathrm{~m}, 2 \mathrm{H},-\mathrm{SCH}_{2} \mathrm{CH}_{2} \mathrm{CH}_{2} \mathrm{O}-\right)$.

Synthesis of PEG Possessing a Pyridyldithio Group at One End and Carboxylic Acid Group at the Other Chain End (Pyridyl-SS-PEG-COOH)

For the preparation of pyridyl-SS-PEG-COOH, the selective hydrolysis of the end thioester group at one end of $\mathrm{CH}_{3} \mathrm{C}(=\mathrm{O}) \mathrm{S}-\mathrm{PEG}-\mathrm{COOH}$ was carried out using $n$-propylamine. The obtained $\mathrm{CH}_{3} \mathrm{C}(=\mathrm{O}) \mathrm{S}-\mathrm{PEG}-$ $\mathrm{COOH}(0.025 \mathrm{mmol})$ and 2-PDS $(0.125 \mathrm{mmol})$ was dissolved in $10 \mathrm{~mL}$ of dry THF. $n$-Propylamine $(0.5$ mmol) was the added to the mixture solution and stirred for $90 \mathrm{~h}$ at room temperature. After the predicted time, an aliquot of the reaction mixture was sampled by a syringe and analyzed by ${ }^{1} \mathrm{H}$ NMR spectroscopy and UV/vis spectroscopy (at $360 \mathrm{~nm}$ ) to confirm the hydrolysis. After the conversion reaction was completed, the obtained polymer was precipitated into diethyl ether and separated by filtration. The precipitate was dried in vacuo. Finally, the obtained polymer was subjected to freeze-drying with benzene. The quantitative installation of the meccapto end group was confirmed by ${ }^{1} \mathrm{H}$ NMR spectroscopy and TOF-MS. ${ }^{1} \mathrm{H}$ NMR $\left(400 \mathrm{MHz}\right.$, DMSO- $\left.d_{6}\right): \delta 8.50-7.20(\mathrm{~m}$, $5 \mathrm{H}$, pyridynyl group), $4.20-4.25\left(\mathrm{~m}, 2 \mathrm{H},-\mathrm{CH}_{2} \mathrm{CH}_{2}-\right.$ $\mathrm{OC}(=\mathrm{O})-), 3.40-3.85\left(\mathrm{~m}, 184 \mathrm{H},-\mathrm{CH}_{2} \mathrm{CH}_{2} \mathrm{O}-\right), 2.85-$ 3.00 (t, $\left.2 \mathrm{H}, \mathrm{HSCH}_{2} \mathrm{CH}_{2}-\right), 2.58-2.62(\mathrm{t}, 4 \mathrm{H},-\mathrm{C}(=\mathrm{O})-$ $\left.\mathrm{CH}_{2} \mathrm{CH}_{2} \mathrm{C}(=\mathrm{O})-\right), 1.80-1.95\left(\mathrm{~m}, 2 \mathrm{H},-\mathrm{SCH}_{2} \mathrm{CH}_{2}-\right.$ $\left.\mathrm{CH}_{2} \mathrm{O}_{-}\right)$.

\section{Characterization}

Size exclusion chromatography (SEC) measurements were carried out using a TOSOH HLC8120 equipped with TSK gel columns (TSKgel SuperHZ3000 and SuperHZ2500) with an internal refractive index (RI) detector. THF containing $0.5 \mathrm{wt} \%$ triethylamine was used as the eluent at a flow rate of $0.35 \mathrm{~mL} / \mathrm{min}$ at $40^{\circ} \mathrm{C}$. Commercially available stand- 
ard PEG oligomers were used for the calibration. The ${ }^{1} \mathrm{H}$ NMR spectra were monitored by a JEOL EX400 spectroscopy at $400 \mathrm{MHz}$ in chloroform- $d$ or DMSO$d_{6}$. The matrix-assisted laser desorption ionizationtime of flight-mass spectra (MALDI-TOF-MS) were recorded using a Bruker Reflex II. 2,5-Dihydroxybenzoic acid (DHB) was used as the matrix for the ionization and operated in the reflection mode. Commercially available standard PEG oligomers were used for the calibration of the detected ions. UV/vis absorbance measurements were carried out using a Shimadzu UV-2400PC spectrometer with a $1-\mathrm{cm}$ quartz cell. The UV-light source was a SAN-EI Electric Supercure-352S. The UV-light was irradiated through an optical fiber equipped with uniform irradiation lens SQL-U. The illumination intensity was measured using an Ushio UIT-150.

\section{Preparation of Biding Assay Surface for Surface Plas- mon Resonance (SPR) Analysis}

Five microliters of $1 \mathrm{M}$ dithiothreitol (DTT) solution was added to $200 \mu \mathrm{L}$ of pyridyl-SS-PEG-COOH aqueous solution $(5 \mathrm{mg} / \mathrm{mL})$ and stirred for $1 \mathrm{~h}$ at $37^{\circ} \mathrm{C}$ to cleave the protective group. The obtained HS-PEG-COOH was purified by a column separation using a NAP-5 column with sephadex G-25 (Amersham Biosciences), viz., $1 \mathrm{~mL}$ of HS-PEG-COOH fraction was eluted by PBS solution $(50 \mathrm{mM}$ phosphate buffer, $\mathrm{pH} 7.4$, containing $150 \mathrm{mM} \mathrm{NaCl}$ ). The bare gold SPR sensor chip was cleaned using a UV/ ozone chamber for $15 \mathrm{~min}$ just prior to use. The PEG modified sensor chip was prepared by immersing the cleaned sensor chip into the PEG-SH solution $\left(\right.$ HS-PEG-COOH $\left(M_{\mathrm{n}}=2000,1 \mathrm{mg} / \mathrm{mL}\right)$ or acetalPEG-SH $\left.{ }^{24}\left(M_{\mathrm{n}}=2000,1 \mathrm{mg} / \mathrm{mL}\right)\right)$ for $2 \mathrm{~h}$ at room temperature, followed by the washing with purified water. The carboxyl group at the PEG tethered chain end was activated as follows: To a mixture of DMF $(1.8 \mathrm{~mL})$ and water $(200 \mu \mathrm{L}), 5 \mathrm{mg}$ of $N$-hydroxysuccinimide (NHS) and $3 \mathrm{mg}$ of $N$-ethyl- $N^{\prime}$-(3-dimethylaminopropyl)carbodiimide hydrochloride (EDC) were dissolved. The PEG-COOH tethered chain surface was immersed to the solution and stand for $30 \mathrm{~min}$ at room temperature. The active ester-PEG sensor chip thus prepared was washed with DMF and reacted with human IgG $(1 \mu \mathrm{M})$ borate buffer solution $(\mathrm{pH}$ 8.5 , containing $150 \mathrm{mM} \mathrm{NaCl}$ ) for $30 \mathrm{~min}$ at room temperature. After the immobilization, the remaining active ester was blocked by $1 \mathrm{M}$ ethanolamine solution ( $\mathrm{pH}$ 8.6). The immobilization of human $\mathrm{IgG}$ on the acetal-ended PEG tethered chain surface was carried our as follows: The acetal-PEG-SH anchored SPR sensor chip was immersed in dilute hydrochloric acid $(0.1 \mathrm{~mol} / \mathrm{L})$ for $1 \mathrm{~h}$ at room temperature to convert the acetal group to an aldehyde group and washed with purified water. To the obtained aldehyde-PEG surface was immersed into human $\operatorname{IgG}(1 \mu \mathrm{M})$ borate buffer solution ( $\mathrm{pH} 8.5$, containing $150 \mathrm{mM} \mathrm{NaCl}$ ) for $2 \mathrm{~h}$ at room temperature to form Schiff base, followed by the addition of $20 \mu \mathrm{L}$ of $1 \mathrm{M}$ borane dimethylamine complex $\left(\left(\mathrm{CH}_{3}\right)_{2} \mathrm{NHBH}_{3}\right)$ solution to reduce formed Schiff base. The obtained human IgG-PEG surfaces were washed with purified water, and then dried in air.

\section{Binding Assay}

Binding experiments were carried out by using a surface plasmon sensor (SPR, BIAcore 3000, Biacore). Anti-human $\operatorname{IgG}(1 \mu \mathrm{M})$ PBS solution at a flow rate of $5 \mu \mathrm{L} / \mathrm{min}$ was used to form human $\mathrm{IgG} /$ antihuman IgG complexes on the chip surface. (BSA $(1 \mu \mathrm{M})$ in PBS solution was used as a control.) The amount of the anti-human IgG was monitored by the SPR angle.

\section{RESULT AND DISCUSSION}

Synthesis of PEG Having an Allyl Group at One End and a Carboxylic Acid Group at the Other Chain End (Allyl-PEG-COOH)

The allyl group is well known to convert versatile types of functional groups, such as amino-, carboxyl-, hydroxyl- and mercapto-groups via an effective addition reaction in the presence of a radical generator. ${ }^{28}$ Thus, PEG with an allyl end group can be one of the most useful candidates to introduce a functionality. For the preparation of the heterotelechelic PEG with a carboxylic acid at one end and a mercapto group at the other chain end, allyl-PEG-COOH was prepared as a precursor. The anionic polymerization of EO was carried out using potassium allyl alcoholate as the initiator. After the polymerization, succinic anhydride was added to the $\omega$-alcoholate to modify a carboxyl group (Scheme 1).

Figure 1 shows the size exclusion chromatography of the obtained polymer. Only a unimodal peak was observed with no shoulder, and the number-average molecular weight $\left(M_{\mathrm{n}}\right)$ and the molecular weight distribution (MWD) were determined to be 2,030 and 1.08 , respectively, using a calibration curve calculated with standard PEG. The obtained polymer was a narrow MWD and the $M_{\mathrm{n}}$ from the SEC data was in good agreement with that calculated from the monomer/initiator ratio, indicating that the EO polymerization initiated from the potassium allyl alcoholate was accomplished without any side reaction. After the purification of the obtained polymer (yield $>90 \%$ ), the efficiency of the $\omega$-end functionalization was done by ${ }^{1} \mathrm{H}$ NMR spectroscopy. As shown in Figure 2, a sharp signal at around $2.3 \mathrm{ppm}$ was clearly observed, which is assignable to the ethylene protons between 

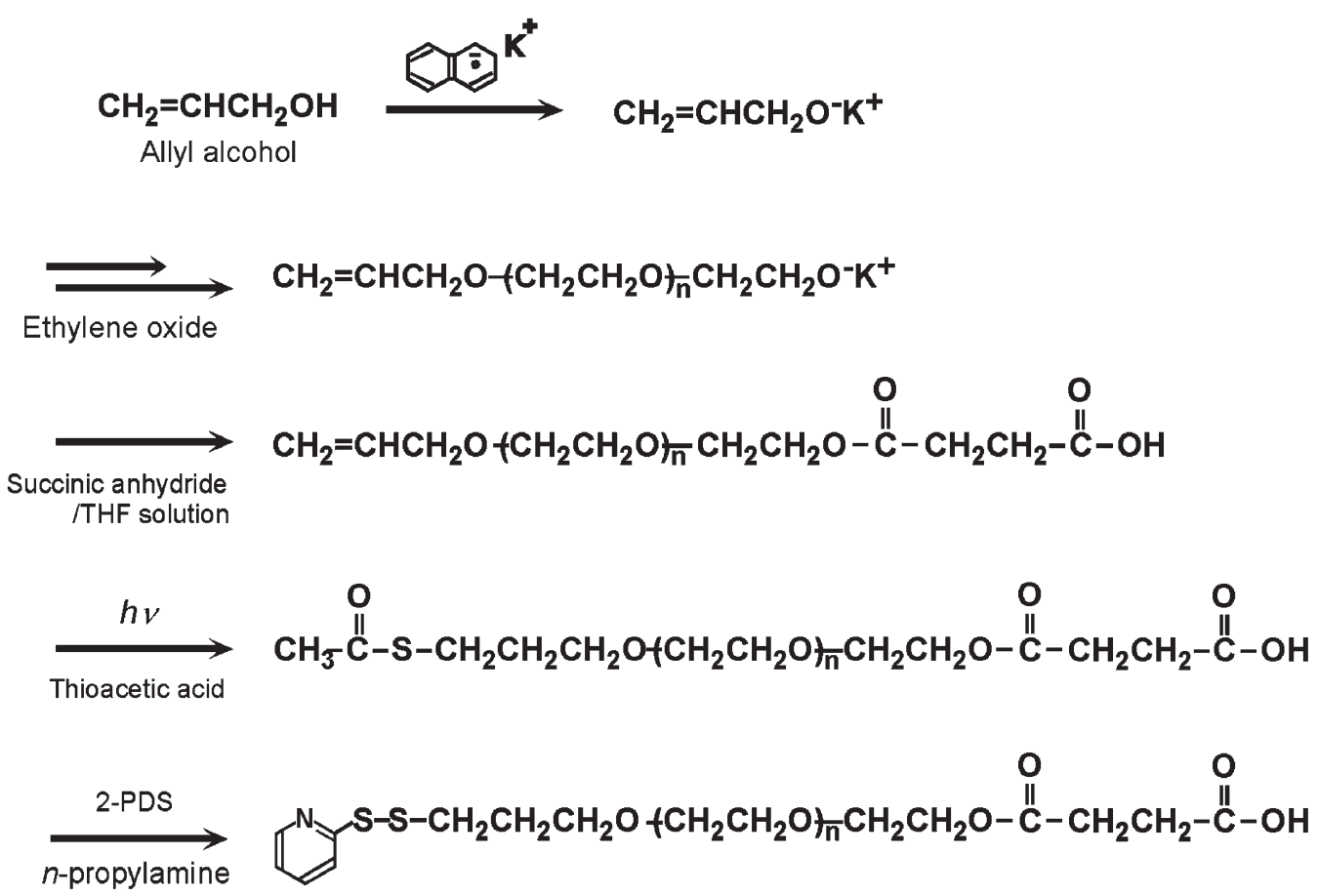

Scheme 1.

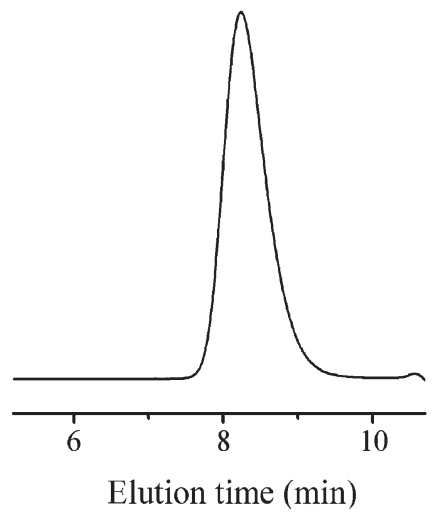

Figure 1. Size exclusion chromatogram of $\alpha$-allyl-PEG$\mathrm{OC}(=\mathrm{O}) \mathrm{CH}_{2} \mathrm{CH}_{2} \mathrm{COOH}$ The molecular weight $\left(M_{\mathrm{n}}\right)$ and the molecular weight distribution (MWD) was calculated by utilizing of standard PEG samples with known molecular weight.

the two carbonyl groups. The integral ratio of the signals at around $5.2 \mathrm{ppm}$, which is assignable to the allyl methylene protons, versus the ethylene signals at around $2.3 \mathrm{ppm}$ was $\mathrm{ca}$. 2:4 indicating that the functionality of the $\omega$-end derivatization was almost complete. The molecular weight determined by the ${ }^{1} \mathrm{H}$ NMR spectrum, viz., the ratio of oxymethylene peak (peak d in Figure 2) versus the methylene protons adjacent to the succinate carbonyl group (peak e in Figure 2) assuming each PEG chain possess the succinate moiety, was 2,700. Thus the Allyl-PEG$\mathrm{OCOCH}_{2} \mathrm{CH}_{2} \mathrm{COOH}$ was quantitatively prepared.
Synthesis of PEG Possessing a Thioester Group at One End and Carboxylic Acid Group at the Other Chain End $\left(\mathrm{CH}_{3} \mathrm{C}(=\mathrm{O}) \mathrm{S}-\mathrm{PEG}-\mathrm{COOH}\right)$

The obtained allyl-PEG-COOH possesses an end double bond. If the double bond shows the same reactivity as that of the low molecular weight allyl compounds, the derivatization of the PEG end will be feasible. The radical addition reaction of thioacetic acid to the allyl end group was carried out in the presence of a radical generator, AIBN, at $60^{\circ} \mathrm{C}$. Even for a several day reaction, however, it was impossible to complete the conversion reaction (data not shown). On the contrary, when the reaction was carried our under UV irradiation at room temperature, ${ }^{29}$ the conversion reaction smoothly proceeded, which was confirmed by SEC and NMR. As can be seen in Figure 3, the SEC profile after the radical addition reaction under UV irradiation did not change very much. No shoulder peak was observed on the higher molecular weight side. It should be noted that the radical coupling reaction took place to some extent when the reaction was carried out at a rather higher temperature as well as at a lower radical generator concentration (data not shown). From the ${ }^{1} \mathrm{H}$ NMR analysis after the purification of the obtained polymer (yield $>90 \%$ ), the peaks corresponding to the allyl end group at 5-6 ppm completely disappeared. Three new peaks corresponding to the thioester end group $\left(\mathrm{CH}_{3} \mathrm{C}(=\mathrm{O}): 2.3 \mathrm{ppm}\right.$, $\left.\mathrm{SCH}_{2} \mathrm{CH}_{2} ; 2.9 \mathrm{ppm}, \mathrm{SCH}_{2} \mathrm{CH}_{2} ; 1.8 \mathrm{ppm}\right)$ appeared in the same spectrum. The molecular weight determined by the ${ }^{1} \mathrm{H}$ NMR spectrum, viz., the ratio of oxymethy- 


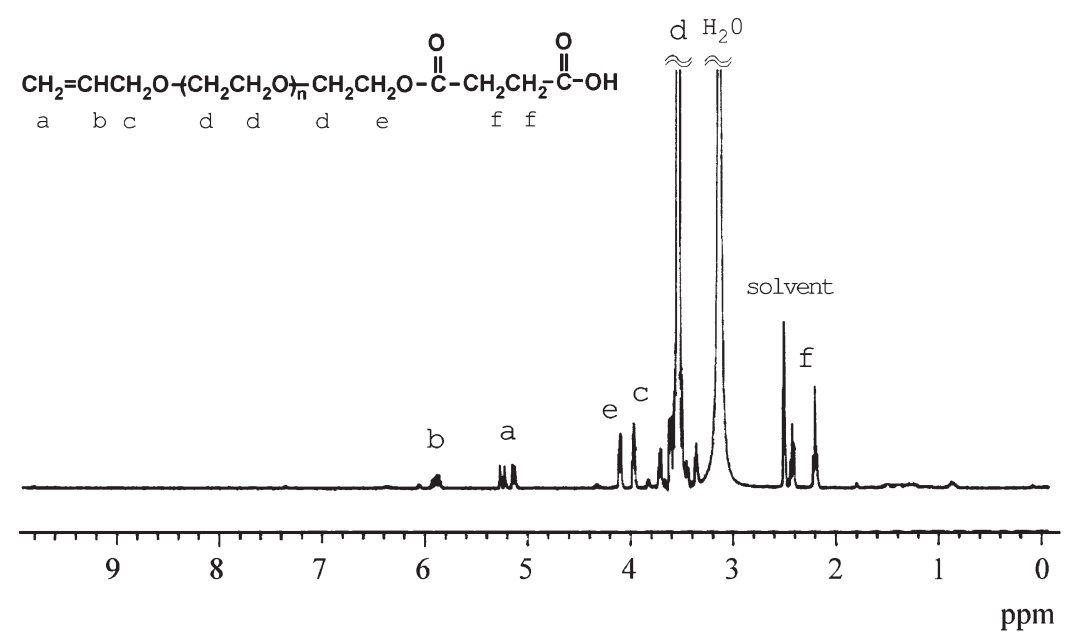

Figure 2. ${ }^{1} \mathrm{H}$ NMR spectrum of $\alpha$-allyl-PEG-OC $(=\mathrm{O}) \mathrm{CH}_{2} \mathrm{CH}_{2} \mathrm{COOH}$ in DMSO- $d_{6}$ at $80^{\circ} \mathrm{C}$.

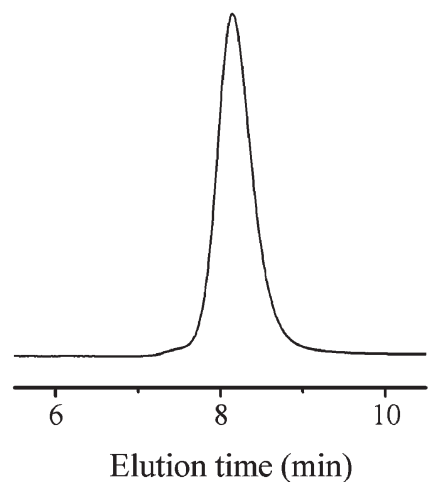

Figure 3. Size exclusion chromatogram of $\mathrm{CH}_{3} \mathrm{C}(=\mathrm{O}) \mathrm{S}-$ $\mathrm{PEG}-\mathrm{OC}(=\mathrm{O}) \mathrm{CH}_{2} \mathrm{CH}_{2} \mathrm{COOH}$.

lene peak (peak d in Figure 4) versus the methylene protons adjacent to the succinate carbonyl group (peak e in Figure 4) assuming each PEG chain possess the succinate moiety, was 2,600 , indicating that the radical modification reaction of the thioacetic acid to the allyl end was almost quantitative without any remarkable side reactions.

Synthesis of PEG Possessing a Pyridildithio Group at One End and Carboxylic Acid Group at the Other Chain End (Pyridyl-SS-PEG-COOH)

By the radical addition reaction under UV irradiation, $\mathrm{CH}_{3} \mathrm{C}(=\mathrm{O}) \mathrm{S}-\mathrm{PEG}-\mathrm{OC}(=\mathrm{O}) \mathrm{CH}_{2} \mathrm{CH}_{2} \mathrm{COOH}$ was selectively obtained. The thioester group is known to be cleaved under alkaline conditions to easily form mercapto group. ${ }^{30}$ When the obtained polymer was reacted with MeONa in THF for $30 \mathrm{~min}$, however, both the thio-ester and oxo-ester were cleaved to form $\mathrm{SH}-$ PEG-OH (data not shown).

To prevent such a hydrolysis reaction on the oxo-ester, a certain selective hydrolysis condition of the thioester end group was investigated. Yang and Drueckhammer reported details on the nucleophilic reactions of both the thio-ester and oxo-ester. When $n$-butylamine was used, the reactivity of the thio-ester

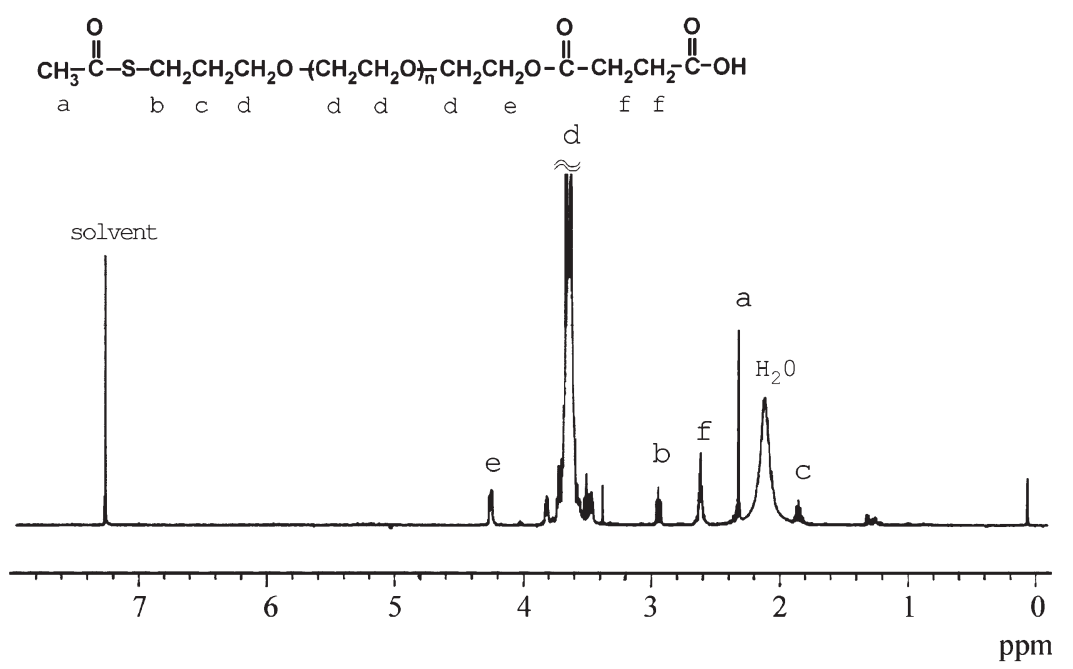

Figure 4. ${ }^{1} \mathrm{H}$ NMR spectrum of $\mathrm{CH}_{3} \mathrm{C}(=\mathrm{O}) \mathrm{S}-\mathrm{PEG}-\mathrm{OC}(=\mathrm{O}) \mathrm{CH}_{2} \mathrm{CH}_{2} \mathrm{COOH}$ in $\mathrm{CDCl}_{3}-d$ at room temperature. 


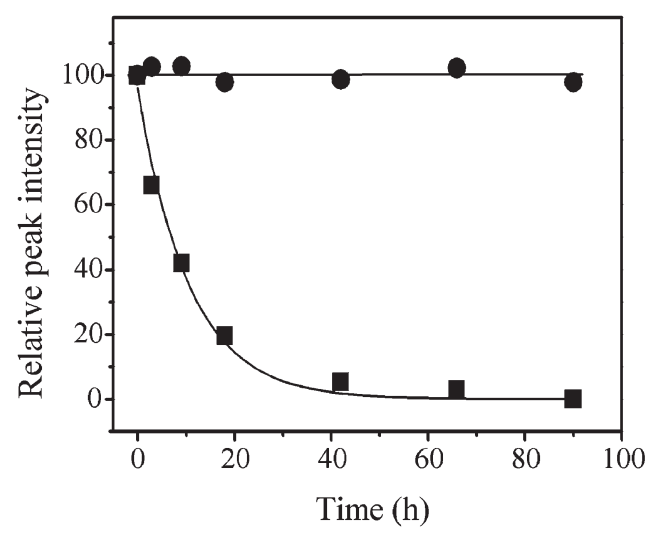

Figure 5. Change in relative peak intensities of methyl protons in thioester ( $\square$ ) and methylene protons adjacent to succinate moiety (-) as a function of reaction time.

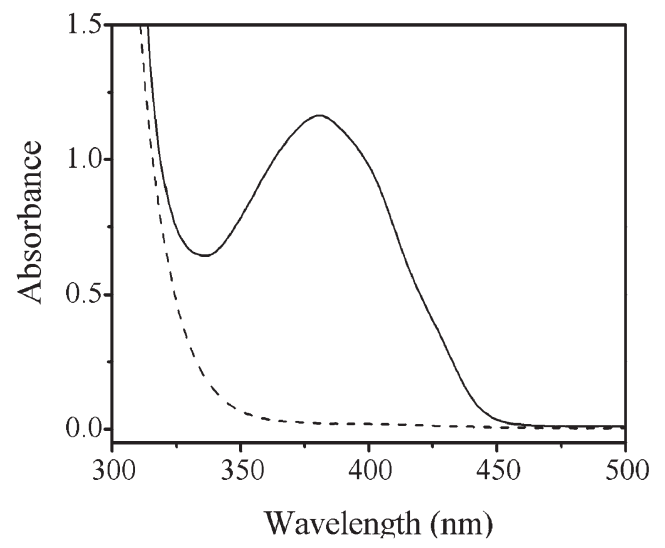

Figure 6. UV absorption spectrum of the $\mathrm{CH}_{3} \mathrm{C}(=\mathrm{O}) \mathrm{S}-\mathrm{PEG}-$ $\mathrm{OC}(=\mathrm{O}) \mathrm{CH}_{2} \mathrm{CH}_{2} \mathrm{COOH}$ dissolved in hydrolysis reaction mixture of 2-PDS and $n$-propylamine in THF (solid line) (dotted line is a control using allyl-PEG-OC $\left.(=\mathrm{O}) \mathrm{CH}_{2} \mathrm{CH}_{2} \mathrm{COOH}\right)$.

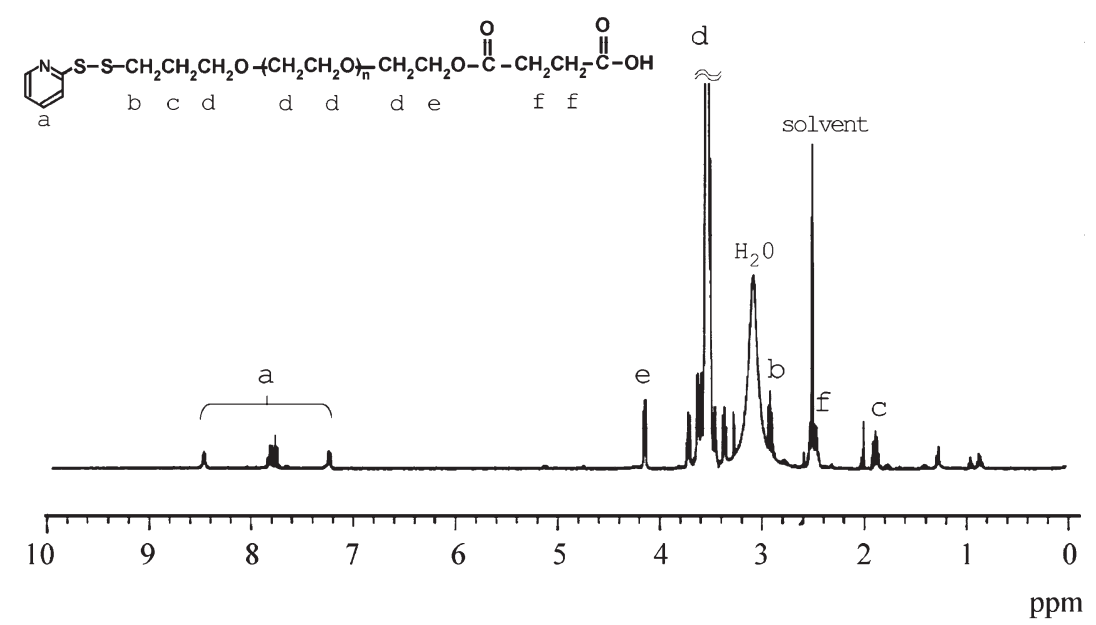

Figure 7. ${ }^{1} \mathrm{H}$ NMR spectrum of pyridyl-SS-PEG-OC( $\left.=\mathrm{O}\right) \mathrm{CH}_{2} \mathrm{CH}_{2} \mathrm{COOH}$ in DMSO- $d_{6}$ at $80{ }^{\circ} \mathrm{C}$.

was 100 -fold greater than that of the oxo-ester. ${ }^{31}$ Thus, the hydrolysis reaction of $\mathrm{CH}_{3} \mathrm{C}(=\mathrm{O}) \mathrm{S}-\mathrm{PEG}-$ $\mathrm{OC}(=\mathrm{O}) \mathrm{CH}_{2} \mathrm{CH}_{2} \mathrm{COOH}$ with $n$-propylamine was examined. The hydrolysis reaction was monitored by the ${ }^{1} \mathrm{H}$ NMR spectra. Figure 5 shows a change in the peak area of both the methyl protons of the thio-ester end (peak a in Figure 4) and the methylene protons adjacent to the succinate moiety (peak e in Figure 4) normalized by the PEG main chain signal (peak $\mathrm{d}$ in Figure 4).

The peak intensity of the thioester group gradually decreased, but the peak intensity of the carboxyl end group retaining intact. It was thus confirmed that the selective deprotection of the thioester group was successfully achieved using $n$-propylamine. The deprotection of the thioester end group was also confirmed by UV/vis spectroscopy. Since the hydrolysis reaction was performed in the presence of 2-PDS, ${ }^{32}$ the liberated SH end group should simultaneously react with 2PDS, which releases an equimolar amount of 2-thio- pyridon $\left(\varepsilon_{360}=5.15 \times 10^{3}\right)$. Figure 6 shows the UV absorption spectra of the hydrolysis reaction mixture in the presence of 2-PDS. The typical broad absorption at $360 \mathrm{~nm}$ was observed in the presence of thioacetate-PEG-COOH, while no absorption was observed when allyl-PEG-COOH was used as the control. One of the other important points of this reaction system is to prevent oxidation of SH-PEG$\mathrm{COOH}$. It is generally known that the thiol end group can be easily oxidized even in atmospheric oxygen. Actually, a fairly high amount of dimeric PEG was observed in the absence of 2-PDS. In the present hydrolysis reaction, no dimerized PEG was obtained, which was confirmed by the SEC. Figure 7 shows the ${ }^{1} \mathrm{H}$ NMR spectrum of the obtained polymer after purification. The peak corresponding to the thioester group at $2.3 \mathrm{ppm}$ had almost disappeared, however, the peaks corresponding to the pyridyl group at around 7.2-8.5 ppm was clearly observed. In addition, the molecular weight determined by ${ }^{1} \mathrm{H}$ NMR spec- 
trum, viz., the ratio of oxymethylene peak (peak d in Figure 7) versus the aromatic protons (peak a in Figure 7), assuming one pyridyl group per each PEG molecule was 2,800 , which was good agreement with that of the SEC data, suggesting that the thioacetatePEG-COOH was successfully transformed into pyridyl-SS-PEG-COOH via a selective deprotection and a specific S-S linkage without any remarkable side reaction.

On the basis of these results, it is confirmed that the heterotelechelic PEG possessing a pyridyldithio group at one end and a carboxyl group at the other chain end was selectively synthesized.

\section{Binding Assay}

We have so far prepared PEG tethered chain surface on gold for high performance biosensor chip using acetal-PEG-SH. The acetal group can be converted to aldehyde group by an acid treatment. A protein can be immobilized on the aldehyde-PEG tethered chains surface via a reductive amination reaction. Due to the protein repelling character of the PEG chains, however, it is not always obtained enough amounts of proteins immobilized on the surface via the reductive amination reaction. When we use carboxyl-ended-PEG-SH, it is possible to construct PEG tethered chains possessing carboxylic acid end group on gold sensor chip. The efficiency of the protein immobilization of the carboxylic-ended PEG tethered chains was compared with that of the aldehydeended one using the SPR sensor.

Figure 8 shows the sensing profiles of anti-human IgG on the human IgG immobilized surfaces. Contrary to the human $\operatorname{IgG}$ immobilized surface via the re-

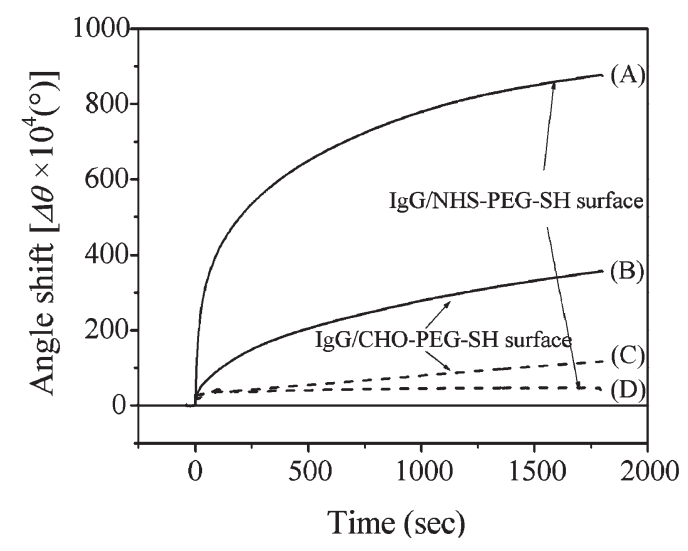

Figure 8. SPR sensorgrams of anti-human IgG binding (solid line) and BSA adsorption (dotted line) on the human IgG immobilized PEG tethered chain surfaces. ((A), (D): human IgG was immobilized via the active ester; (B), (C): human-IgG was immobilized via the reductive amination reaction. Proteins were injected as a $0.1 \mu \mathrm{M}$ PBS solution at a flow rate of $5 \mu \mathrm{L} / \mathrm{min}$ for $30 \mathrm{~min})$. ductive amination, the sensing amount on the $\operatorname{IgG}$ via the active ester immobilization was much higher, indicating the higher immobilization amount on the active ester surface. When BSA was flowed on the surface, non-specific adsorption was suppressed effectively on both surfaces. Further studies on the PEG$\mathrm{COOH}$ sensor chip will be published elsewhere.

\section{CONCLUSIONS}

In order to synthesize the desired types of heterotelechelic PEGs, we started to prepare allyl-PEG-X as a precursor. In the present study, succinic anhydride was reacted at the $\omega$-chain end because we have already confirmed that the acid anhydride quantitatively reacts with potassium alcoholate at the end of PEG chain by just mixing. The radical addition reaction of thioacetic acid to the allyl end group under UV irradiation at ambient temperature completely proceeded to form $\mathrm{CH}_{3} \mathrm{C}(=\mathrm{O}) \mathrm{S}-\mathrm{PEG}-\mathrm{OC}(=\mathrm{O}) \mathrm{CH}_{2} \mathrm{CH}_{2}$ $\mathrm{COOH}$. The selective hydrolysis of the thioester group was accomplished by amine hydrolysis using $n$-propylamine. During the hydrolysis reaction, the oxidization reaction of the preformed SH-PEG-COOH with each other was prevented by the present 2-PDS. Thus, pyridyl-SS-PEG-COOH was selectively synthesized. This reaction scheme can be applied to the other heterotelechelic PEG syntheses, such as amino-PEG$\mathrm{COOH}$ and silanol-PEG-COOH. The PEG tethered chains having carboxylic acid group at the free chain end was constructed on the gold surface, which can be utilized for the effective protein immobilized surface via the active ester chemistry.

\section{REFERENCES}

1. Y. Mori, S. Nagaoka, H. Takiuchi, T. Kikuchi, N. Noguchi, H. Tanzawa, and Y. Noishiki, Trans. Am. Soc. Artif. Intern. Organs, 28, 459 (1982).

2. J. M. Harris, M. R. Sedaghat-Herati, P. J. Sather, D. E. Brooks, and T. M. Fyles, in "Poly(ethylene glycol) Chemistry: Biotechnical and Biomedical Applications," J. M. Harris, Ed., Plenum Press, New York, N.Y., 1992.

3. F. E., Jr. Bailey and J. V. Koleske, Ed., "Alkylene Oxide and Their Polymers, Vol. 35," Marcel Dekker, New York, N.Y., 1991.

4. F. Fuertges and A. Abuchowski, J. Controlled Release, 11, 139 (1990).

5. Y. K. Park, A. Abuchowski, S. Davis, and F. Davis, Anticancer Res., 1, 373 (1981).

6. R. Ramachandran, D. Katzenstein, M. A. Winters, S. K. Kundu, and T. C. Merigan, J. Infect. Dis., 173, 1005 (1996).

7. K. Kataoka, A. Harada, and Y. Nagasaki, Adv. Drug Delivery Rev., 47, 113 (2001).

8. Y. Deguchi, A. Kurihara, and W. M. Pardridge, Bioconjugate Chem., 10, 32 (1999). 
9. R. B. Greenwald, K. Yang, H. Zhao, C. D. Conover, S. Lee, and D. Filpula, Bioconjugate Chem., 14, 395 (2003).

10. H. Otsuka, Y. Nagasaki, and Kataoka, Curr. Opin. Colloid Interface Sci., 6, 3 (2001).

11. A. Kurihara and W. M. Pardridge, Bioconjugate Chem., 11, 380 (2000).

12. E. C. Unger, D. Shen, G. Wu, L. Stewart, T. O. Matsunaga, and T. P. Trouard, Magn. Reson. Mater. Phys., Biol. Med., 8, 154 (1999).

13. V. P. Torchilin, Colloids Surf. B., 16, 305 (1999).

14. J. D. Andrade, V. Hlady, and S.-I. Jeon, in "Hydrophilic Polymers: Poly(ethylene oxide) and Protein Resistance," J. E. Glass, Ed., American Chemical Society, Washington, D.C., 1996, p. 51.

15. M. Hasan, D. Bethell, and M. Brust, J. Am. Chem. Soc., 124, 1132 (2002).

16. H. Otsuka, Y. Akiyama, Y. Nagasaki, and K. Kataoka, J. Am. Chem. Soc., 47, 8226 (2001).

17. W. P. Wuelfing, S. M. Grass, D. T. Miles, and R. W. Murray, J. Am. Chem. Soc., 120, 12696 (1998).

18. Y. Nagasaki, T. Kutsuna, M. Iijima, M. Kato, K. Kataoka, S. Kitano, and Y. Kodama, Bioconjugate Chem., 6, 231 (1995).

19. T. Nakamura, Y. Nagasaki, M. Kato, and K. Kataoka, in "Biomedical Engineering and Drug Delivery System: Synthesis of Heterobifunctional Poly(ethylene glycol) with a Reducing Monosaccharide Residue at One End for Drug Delivery, Systems," N. Ogata, S. W. Kim, J. Fijen, and T. Okano, Ed., Springer, Tokyo, 1996.
20. Y. Nagasaki, M. Iijima, M. Kato, and K. Kataoka, Bioconjugate Chem., 6, 702 (1995).

21. S. Cammas, Y. Nagasaki, and K. Kataoka, Bioconjugate Chem., 6, 226 (1995).

22. Y. Akiyama, Y. Nagasaki, and K. Kataoka, Bioconjugate Chem., 15, 424 (2004).

23. M. Oishi, T. Tsuruta, K. Kataoka, and Y. Nagasaki, to be submitted.

24. Y. Akiyama, H. Otsuka, Y. Nagasaki, M. Kato, and K. Kataoka, Bioconjugate Chem., 11, 947 (2000).

25. K. Uchida, H. Otsuka, Y. Nagasaki, and K. Kataoka, to be submitted.

26. O. Rheingans, N. Hugenberg, J. R. Harris, K. Fischer, and M. Maskos, Macromolecules, 33, 4780 (2000).

27. H. Hayashi, M. Iijima, K. Kataoka, and Y. Nagasaki, Macromolecules, 37, 5389 (2004).

28. C. M. Starks, "Free Radical Telomerization," Academic Press, New York, N.Y., 1974.

29. S. Herrwerth, T. Rosendahl, C. Feng, J. Fick, W. Eck, M. Himmelhaus, R. Dahint, and M. Grunze, Langmuir, 19, 1880 (2003).

30. T. W. Green and P. G. M. Wuts, "Protective Groups in Organic Synthesis, 3rd ed.," John Wiley \& Sons, New York, N.Y., 1999.

31. W. Yang and D. G. Drueckhammer, J. Am. Chem. Soc., 123, 11004 (2001).

32. T. Uete, Y. Miyamoto, M. Ohnishi, and N. Shimano, Clin. Chem., 18, 454 (1972). 